\title{
Knowledge of nursing students on vasculogenic lesions
}

\author{
Conhecimento de acadêmicos de Enfermagem sobre lesões vasculogênicas
}

Raísa Leocádio Oliveira' ${ }^{1}$, Lariza Martins Falcão ${ }^{1}$, Elaine Cristina Carvalho Moura ${ }^{1}$, Fernanda Valeria Silva Dantas Avelino $^{1}$, Raylane da Silva Machado ${ }^{1}$

Objective: to assess the knowledge of nursing students on vasculogenic lesions. Methods: cross-sectional and descriptive study conducted in four higher education institutions. Researchers applied a questionnaire to 106 nursing students, which was composed of variables, such as school situation, prior contact and knowledge of students on the subject. Results: the mean score on the characteristics of vasculogenic lesions was higher among public institutions academic (33.0\%), among those who reported having provided nursing care for patients with these lesions (37.7\%) and among those who claimed to know the difference between venous lesions and arterial lesions (25.5\%). The higher amount of correct answers on venous lesions was related to the coloration in perilesional area (74.5\%); and on arterial lesions, regarding habits and underlying diseases (67.0\%). Conclusion: academics who have practical experience in the care of patients with vasculogenic lesions during undergraduate course had higher theoretical knowledge on the subject.

Descriptors: Nursing; Schools; Knowledge; Leg Ulcer.

Objetivo: avaliar o conhecimento de acadêmicos de Enfermagem sobre lesões vasculogênicas. Métodos: estudo transversal, descritivo, realizado em quatro instituições de educação superior. Aplicou-se um questionário para 106 acadêmicos de Enfermagem, o qual foi composto por variáveis, como: situação escolar, contato prévio e conhecimento dos alunos sobre a temática. Resultados: a média de acertos sobre as características de lesões vasculogênicas foi superior entre acadêmicos de instituições públicas (33,0\%), entre os que referiam ter prestado assistência de enfermagem a pacientes com essas lesões $(37,7 \%)$ e os que alegaram saber diferenciar lesões venosas de lesões artérias (25,5\%). A maior quantidade de acertos sobre as lesões venosas estava relacionada à coloração em região perilesão (74,5\%); e nas lesões arteriais, a hábitos e doenças de base (67,0\%). Conclusão: os acadêmicos que tiveram experiência prática no cuidado a pacientes com lesões vasculogênicas durante a graduação possuíam maior conhecimento teórico sobre a temática.

Descritores: Enfermagem; Instituições Acadêmicas; Conhecimento; Úlcera da Perna.

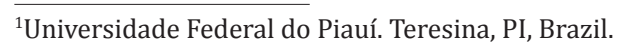




\section{Introduction}

Vasculogenic lesions, also known as leg injury, are considered chronic wounds to be long-lasting and because the healing process lasts weeks or even years. These lesions affect the distal third of the lower limbs and impair the skin and surrounding tissues; they are recurrent, disabling, cause a lot of pain, reverberate negatively in ambulation, require long and complex treatment and cause psychosocial changes ${ }^{(1-2)}$.

In Brazil, the number of people affected by skin lesions has contributed to encumber public spending. Wounds are a serious public health problem because, despite underreporting, individuals affected by a lesion, regardless of its etiology, have decreased quality of life and require specific treatment ${ }^{(3)}$.

The etiology of leg injuries is associated with several factors, such as chronic venous disease, peripheral arterial disease, neuropathies, hypertension, physical trauma, sickle cell anemia, skin infections, inflammatory diseases, cancer and nutritional changes ${ }^{(4)}$. Among the leg injuries, about 80.0 to $85.0 \%$ are venous lesions, 5.0 to $10.0 \%$ have arterial origin and the remainder is classified as neuropathic or mixed lesion ${ }^{(5)}$.

Vasculogenic lesions are described as a chronic, painful, periodic process, with a negative impact on quality of life, mobility, emotional state and functional capacity of affected people, requiring multidisciplinary care with local and systemic interventions. Treatment of these wounds is a challenge for both the person affected and for health professionals, because evaluating them and treat them requires from the health professional a higher level of knowledge, not to cause misdiagnosis or delay in the healing process ${ }^{(6-7)}$.

The correct diagnosis so that professionals adopt appropriate specific therapeutic measures depends directly on their knowledge. Thus, the work of a multidisciplinary team in which nursing is inserted is essential. The nurse stands out for providing care with expanded evaluation of people with vasculogenic lesions: they evaluate injuries, make dressings and referrals and promote educational activities for favorable evolution of the healing process and prevention of the onset of lesions and occurrence of relapse $\mathrm{e}^{(8)}$.

These actions are possible when the nurse understands the tissue repair process, can identify the underlying disease and its implications, as well as has knowledge of the clinical and histopathological features of the lesions. Thus, it is crucial that the nurse is qualified, able and willing to care for patients with vasculogenic injuries.

In view of this, the present study aimed to assess the knowledge of nursing students on vasculogenic injuries.

\section{Methods}

This is a cross-sectional and descriptive study conducted in four higher education institutions in the city of Teresina, Piaui, northeast Brazil. In this city, there are 14 nursing schools, and the population was selected from four of these. The institutions participating in the survey were chosen by convenience, considering the inclusion of public and private education institutions. Thus, two public universities and two private universities were selected in order not to limit the study to a single type of institution and to allow the comparison of results.

The population consisted of 131 students of the Nursing course who were enrolled in the penultimate semester of the undergraduate course, in the academic year 2015, of the selected institutions. Inclusion criteria to compose the sample were being older than 18 and being present in the classroom at the time of the interview. Considering these criteria, 106 students participated in the study.

Data collection occurred from September to November 2015 and a questionnaire made by the researchers in order to investigate the knowledge of academics on the subject was used as data collection instrument. The questionnaire was composed of the following parts: sociodemographic and socioeconomic 
characteristics; information sources and school situation; prior contact with the subject and analysis of knowledge about vasculogenic lesion.

Questions analyzing knowledge of vasculogenic lesions were prepared based on clinical protocols and renowned authors on this theme. These questions were formulated as statements, in which the answer options were "true," "false" or "I do not know". The evaluation of the scores was performed by using the proportion of correct answers in each item, and the wrong answers or said as "I do not know" were counted as errors. Each affirmative answered correctly corresponded to the value of 1 (one) score, and the questionnaire corresponded to 76 scores.

Before applying the questionnaire in the selected classes, researchers conducted a pilottest with 10 students attending the last period of the Nursing course of one of the selected public institutions. Then, the researcher applied the questionnaire in the four higher education institutions, in the classroom, in a single moment, with all the students of the selected class, in order to ensure greater methodological reliability to the process.

The analysis and processing of data occurred in the Statistical Package for the Social Sciences ${ }^{\circledR}$ program, version 20.0. Quantitative variables were expressed as mean ( \pm standard deviation), minimum and maximum, and categorical variables were expressed as frequencies and proportions. The normality of the results was assessed by KolmogorovSmirnov test and homogeneity of variance, by Levene's test. The data that showed homogeneity of variance were evaluated by Student's t-test for independent samples, with a significance of $5.0 \%$. The results that did not achieve homogeneity of variance were evaluated by the Mann-Whitney U test.

The study complied with the formal requirements contained in the national and international regulatory standards for research involving human beings.

\section{Results}

The study enrolled 106 nursing students, distributed in public and private institutions. Table 1 presents data on the socioeconomic and sociodemographic characteristics of this sample.

Table 1 - Sociodemographic and economic characterization of nursing students $(n=106)$

\begin{tabular}{|c|c|c|}
\hline Characteristics & n(\%) & $(\mathrm{CI}$ 95\%)** \\
\hline \multicolumn{3}{|l|}{ Age (years) } \\
\hline $20-29$ & $91(85.8)$ & $79.2-91.5$ \\
\hline $30-39$ & $10(9.4)$ & $4.7-15.1$ \\
\hline $40-49$ & $3(2.8)$ & $0.0-6.6$ \\
\hline Did not answer & $2(1.9)$ & $0.0-4.9$ \\
\hline \multicolumn{3}{|l|}{ Marital status } \\
\hline Single & $93(87.7)$ & 81.1- 93.4 \\
\hline Married & $8(7.5)$ & $2.8-12.3$ \\
\hline Divorced & $2(1.9)$ & $0.0-4.7$ \\
\hline Stable union & $2(1.9)$ & $0.0-4.7$ \\
\hline Did not answer & $1(0.9)$ & $0.0-2.8$ \\
\hline \multicolumn{3}{|l|}{ Children } \\
\hline Yes & $17(16.0)$ & $9.5-23.6$ \\
\hline No & $88(83.0)$ & $75.5-89.6$ \\
\hline Did not answer & $1(0.9)$ & $0.0-2.8$ \\
\hline \multicolumn{3}{|l|}{ Family income* } \\
\hline 1 & $9(8.5)$ & $3.8-14.2$ \\
\hline 2 & 23 (21.7) & $14.2-30.2$ \\
\hline 3 & 20 (18.9) & $12.3-26.4$ \\
\hline 4 & $9(8.5)$ & $3.8-14.2$ \\
\hline$>5$ & $13(12.3)$ & $6.6-18.9$ \\
\hline Did not answer & $32(30.2)$ & $21.7-39.6$ \\
\hline \multicolumn{3}{|c|}{ Internet access at home } \\
\hline Yes & $96(90.6)$ & $84.9-96.2$ \\
\hline No & $9(8.5)$ & $3.8-14.2$ \\
\hline Did not answer & $1(0.9)$ & $0.0-2.8$ \\
\hline
\end{tabular}


Table 2 shows that the sample was predominantly female (89.6\%) and of students and private institutions (67.0\%). In addition, it presents comparative data between the averages of correct answers regarding the students' knowledge on vasculogenic lesions and the variables of gender and previous contact with the subject.

According to Table 2, there was no statistically significant difference between the average number of correct answers of female $(\mathrm{m}=32.08)$ and male students $(m=37,00)$, as well as among those who had attended classed on vasculogenic lesion during undergraduate course $(m=33.41)$, had sought literature on the subject $(\mathrm{m}=35.46)$, had participated in events on the subject $(\mathrm{m}=37.25)$ and were inserted in research groups on vasculogenic lesions $(m=8,00)$.
However, Table 2 shows that the average of correct answers of students from public universities $(m=36.83)$ was statistically higher than the average of correct answers of students from private institutions $(\mathrm{m}=30.51)$. Those who had provided care for patients with vasculogenic lesions during undergraduate course $(37.7 \%)$ had more correct answers $(m=37.45)$. Students who reported knowing the difference between the types of vasculogenic lesions (25.5\%) also had the highest number of correct answers $(\mathrm{m}=37.00)$.

Table 3 shows that the p-value was 0.019 , which demonstrates that the average number of correct answers regarding the knowledge of venous lesions of students from public institutions was statistically higher when compared to students from private institutions.

Table 2 - Variables on gender and previous contact with the subject and the mean score for knowledge of nursing students $(\mathrm{n}=106)$ on vasculogenic injuries

\begin{tabular}{|c|c|c|c|c|}
\hline \multirow{2}{*}{ Variables } & \multirow{2}{*}{$\mathbf{n}(\%)$} & \multicolumn{2}{|c|}{$\begin{array}{c}\text { Total scores of correct } \\
\text { answers }(n=106)\end{array}$} & \multirow{2}{*}{ p-value } \\
\hline & & (CI95\%) & $\begin{array}{c}\text { Mean } \pm \text { standard } \\
\text { deviation }\end{array}$ & \\
\hline \multicolumn{5}{|l|}{ Gender } \\
\hline Male & $11(10.4)$ & $4.7-17.0$ & $37.00 \pm 7.84$ & \multirow{2}{*}{0.237} \\
\hline Female & $95(89.6)$ & $83.0-95.3$ & $32.08 \pm 13.40$ & \\
\hline \multicolumn{5}{|l|}{ University } \\
\hline Public & $35(33.0)$ & $23.6-42.5$ & $36.83 \pm 9.67$ & \multirow{2}{*}{$0.008^{* *}$} \\
\hline Private & $71(67.0)$ & $57.5-76.4$ & $30.51 \pm 13.95$ & \\
\hline \multicolumn{5}{|c|}{ Had attended class on vasculogenic lesion during undergraduate course } \\
\hline Yes & $61(57.5)$ & $47.2-67.0$ & $33.41 \pm 12.52$ & \multirow{3}{*}{0.445} \\
\hline No & $43(40.6)$ & $31.1-50.0$ & $31.42 \pm 13.75$ & \\
\hline No answer & $2(1.9)$ & $0.0-4.7$ & & \\
\hline \multicolumn{5}{|c|}{ Had provided care for patients with vasculogenic lesion during undergraduate course } \\
\hline Yes & $40(37.7)$ & $29.2-47.2$ & $37.45 \pm 8.97$ & \multirow{3}{*}{$0.001^{* *}$} \\
\hline No & $65(61.3)$ & $50.9-70.8$ & $29.42 \pm 14.16$ & \\
\hline No answer & $1(0.9)$ & $0.0-2.8$ & & \\
\hline \multicolumn{5}{|c|}{ Had searched literature on vasculogenic lesion during undergraduate course } \\
\hline Yes & $39(36.8)$ & $27.4-46.2$ & $35.46 \pm 10.84$ & \multirow{3}{*}{0.083} \\
\hline No & $64(60.4)$ & $50.9-69.8$ & $30.88 \pm 13.98$ & \\
\hline No answer & $3(2.8)$ & $0.0-6.6$ & & \\
\hline \multicolumn{5}{|c|}{ Can differentiate the types of vasculogenic lesions } \\
\hline Yes & $27(25.5)$ & $17.0-34.0$ & $37.00 \pm 10.81$ & \multirow{3}{*}{$0.035^{* *}$} \\
\hline No & $77(72.6)$ & $64.2-81.1$ & $30.86 \pm 13.46$ & \\
\hline No answer & $2(1.9)$ & $0.0-4.7$ & & \\
\hline \multicolumn{5}{|c|}{ Had participated in events on the theme } \\
\hline Yes & $12(11.3)$ & $5.7-17.9$ & $37.25 \pm 10.50$ & \multirow{3}{*}{0.183} \\
\hline No & $91(85.8)$ & $78.3-92.5$ & $31.87 \pm 13.35$ & \\
\hline No answer & $3(2.8)$ & $0.0-6.6$ & & \\
\hline \multicolumn{5}{|c|}{ Insertion in research groups on the subject } \\
\hline Yes & $2(1.9)$ & $0.0-4.7$ & $38.00 \pm 15.56$ & \multirow{3}{*}{0.555} \\
\hline No & $100(94.3)$ & $88.7-98.1$ & $32.39 \pm 13.23$ & \\
\hline No answer & $4(3.8)$ & $0.9-8.5$ & & \\
\hline
\end{tabular}


Table 3 - Distribution of means ( \pm standard deviation), median, minimum, maximum and mean standard error of correct answers of nursing students ( $\mathrm{n}=$ 106) of public and private institutions regarding the knowledge on venous vasculogenic lesions

\begin{tabular}{lccccc}
\hline $\begin{array}{l}\text { Scores of correct } \\
\text { answers }^{\mathbf{a}}\end{array}$ & Median & $\begin{array}{c}\text { Min- } \\
\text { Max }\end{array}$ & $\begin{array}{c}\text { Mean ( } \pm \text { Stan- } \\
\text { dard Deviation) }\end{array}$ & $\begin{array}{c}\text { Mean stan- } \\
\text { dard error }\end{array}$ & p-value \\
\hline Total & 17.00 & $0-31$ & $16.83 \pm 6.24$ & 0.607 & \\
Public institution & 19.00 & $9-31$ & $18.63 \pm 4.63$ & 0.783 & $0.019^{*}$ \\
Private institution & 17.00 & $0-27$ & $15.94 \pm 6.76$ & 0.802 & \\
\hline
\end{tabular}

a38 questions in total. * Student's t-test assuming equal variances

Table 4 shows that the p-value was 0.042 , which evidences significant difference between the number of correct answers regarding the knowledge of arterial lesions of students from public and private institutions, which was higher among students from public institutions.

When comparing the number of correct answers regarding the knowledge of venous and arterial lesions, both in public and private institutions,
Table 4 - Distribution of means ( \pm standard deviation), median, minimum, maximum and mean standard error of correct answers of nursing students ( $\mathrm{n}=$ 106) of public and private institutions regarding the knowledge on arterial vasculogenic lesions

\begin{tabular}{lccccc}
$\begin{array}{l}\text { Scores of correct } \\
\text { answers }^{\mathbf{a}}\end{array}$ & Median & $\begin{array}{c}\text { Min- } \\
\text { Max }\end{array}$ & $\begin{array}{c}\text { Mean ( } \pm \text { Stan- } \\
\text { dard Deviation) }\end{array}$ & $\begin{array}{c}\text { Mean stan- } \\
\text { dard error }\end{array}$ & p-value \\
\hline Total & 18.00 & $0-28$ & $15.76 \pm 7.86$ & 0.764 & \\
Public institution & 19.00 & $1-28$ & $18.20 \pm 6.46$ & 1.092 & $0.042^{*}$ \\
Private institution & 17.00 & $0-27$ & $14.56 \pm 8.25$ & 0.979 & \\
\hline
\end{tabular}

a38 questions. * Mann Whitney U test

the largest number of correct questions was referring to questions on venous vasculogenic lesions.

Table 5 shows that the higher amount of correct answers regarding venous lesions was related to the coloration in perilesional area (74.5\%); and on arterial lesions, habits and underlying diseases (67.0\%). With respect to the highest number of wrong answers, both on venous $(94.3 \%)$ and arterial lesions $(84.9 \%)$, these were related to the use of ultrasound as a treatment.

Table 5 - Distribution of questions with the highest and lowest number of correct answers among nursing students $(\mathrm{n}=106)$

\begin{tabular}{|c|c|c|c|c|}
\hline Questions & $\begin{array}{l}\text { Correct answers } \\
\mathbf{n}(\%)\end{array}$ & (CI 95\%) & $\begin{array}{l}\text { Wrong answers } \\
\text { n(\%) }\end{array}$ & (CI 95\%) \\
\hline \multicolumn{5}{|l|}{ Venous lesions } \\
\hline The area around the lesion undergoes color change $(\mathrm{T})$ & $79(74.5)$ & $66.0-83.0$ & $27(25.5)$ & $17.0-34.0$ \\
\hline It often presents edema $(\mathrm{T})$ & $78(73.6)$ & $65.1-82.1$ & $28(26.4)$ & $17.9-34.9$ \\
\hline It emerges as a serious consequence of Chronic Venous Insufficiency (T) & $76(71.7)$ & $63.2-80.2$ & $30(28.3)$ & $19.8-36.8$ \\
\hline Ultrasound can be used for wound healing ( $\mathrm{T}$ ) & $6(5.7)$ & $1.9-10.4$ & $100(94.3)$ & $89.6-98.1$ \\
\hline $\begin{array}{l}\text { It is usually present in patients who have hypertension, diabetes or are } \\
\text { smokers (F) }\end{array}$ & $13(12.3)$ & $6.6-18.9$ & $93(87.7)$ & $81.1-93.4$ \\
\hline It usually presents necrotic tissue (F) & $18(17.0)$ & $10.4-24.5$ & $88(83.0)$ & $75.5-89.6$ \\
\hline \multicolumn{5}{|l|}{ Arterial lesions } \\
\hline It often presents edema $(\mathrm{T})$ & $70(66.0)$ & $56.6-74.5$ & $36(34.0)$ & $25.5-43.4$ \\
\hline The area around the lesion undergoes color change (T) & $68(64.2)$ & $54.7-73.6$ & $38(35.8)$ & $26.4-45.3$ \\
\hline Ultrasound can be used for wound healing ( $\mathrm{T}$ ) & $16(15.1)$ & $8.5-22.6$ & $90(84.9)$ & $77.4-91.5$ \\
\hline $\begin{array}{l}\text { It is recommended to use antiseptic solution in the lesion and in the } \\
\text { perilesional area }(F)\end{array}$ & $21(19.8)$ & $13.2-27.4$ & $85(80.2)$ & $72.6-86.8$ \\
\hline It is recommended lifting the feet at superior height of the hips (F) & $23(21.7)$ & $14.2-29.2$ & $83(78.3)$ & $70.8-85.8$ \\
\hline
\end{tabular}




\section{Discussion}

This study identified the knowledge of nursing students on vasculogenic ulcers, although it has shown some limitations, such as not applying the questionnaire to all students enrolled in institutions selected for data collection, since the sample was chosen by convenience. This implies limitations in statistical analysis and generalizations.

The other limitation of the study, especially for production of the discussion of the results, was that authors did not find in indexed databases similar articles with the theme of the study in question, a fact that made it difficult to interpret the results because of the lack of this knowledge.

However, it was found that the sample consisted of a large majority of female students, probably because it is a course so closely linked to the professional process of care, a function that has been attributed to the female gender for years. Although the number of women was greater than the number of men in this study, there was no noticeable difference in the level of knowledge among men and women.

Access to grants and to extension research projects with financial incentives for undergraduate process as well as the provision of internet access tend to favor and facilitate access to knowledge and, in general, minimize barriers in search of information among academics from public and private institutions.

Allied to this, during the academic process, educational institutions and health undergraduate courses must adapt to changes in the Brazilian health system and labor market, providing qualified and trained professionals to solve the real needs of the population ${ }^{(9)}$.

When comparing the number of correct answers of the questionnaire items on vasculogenic lesions among public and private institutions, it was found that students of public institutions had more correct answers, either on venous or arterial lesions when compared to students from private institutions. These results can be explained by other current study that used data from the National Survey of Student Performance of 2010 and confirmed that the growing number of private higher education institutions provides the indiscriminate opening of courses that have an increasingly more distant profile from public institutions and which do not reach minimum indicators of educational quality ${ }^{(10)}$.

Other results showed that students who provided nursing care for patients with vasculogenic lesions and who reported knowing the difference between the types of lesions had more correct answers when asked about the issue. This data can be justified by a study that evaluated the knowledge of nurses and found that 23 (31.5\%) of the participants obtained satisfactory results due to the recent completion of course ${ }^{(11)}$. One can conclude that the training of students, even during the nursing course, influences on clinical practice and therefore qualifies the academics' performance in caring for patients ${ }^{(12)}$.

The difficulty of nurses in carrying out proper assessment of wounds can be explained by the lack of experience and specific training ${ }^{(13)}$. This difficulty can be remedied during the undergraduate course itself, given that this study pointed out mistakes and successes on the evaluation of chronic vasculogenic lesions.

In this context, after evaluating the questions with higher number of correct and wrong answers, it was noted increased knowledge and hence number of correct answers in questions involving predisposing conditions for venous and arterial lesions as well as characteristics of the lesions, such as edema and color in the perilesional area. By assuming that clinical practice and theory-practice relationship have a positive effect on the knowledge of academics, it is possible to explain that the recognition of these characteristics of the lesions is acquired during practice and that critical thinking about predisposing diseases and probable outbreak of lesions come from the theory-practice relationship.

The experience as academic will give the nurse support to adopt appropriate procedures. 
Nurses have the responsibility to plan care, select and combine appropriate coverage for lesions, monitor the treatment, establish changes in their own procedures based on a continuous assessment and implement educational process that brings benefits to the patient and promotes self-care ${ }^{(14)}$.

The questions on venous lesions that had more wrong answers were those involving treatment and recognition of the lesion. The questions about arterial lesions that had more wrong answers involved treatment of the disease. This fact is extremely worrying, since the nurse must have excellent knowledge on the treatment of wounds, and it is during the undergraduate process that they will receive theoretical support. This study shows gaps in knowledge on this theme that may be settled in academic training ${ }^{(15)}$.

Based on the results, nursing students had shortcomings as regards the vasculogenic skin lesions, particularly those of vascular origin. Thus, it is expected that this study can serve as a reflection on the theme during the Nursing undergraduate course.

\section{Conclusion}

It was statistically proven that students who performed nursing care during undergraduate course to patients with vasculogenic lesions had greater knowledge thereof when compared to those who did not have this opportunity. Regarding the type of vasculogenic lesions that nursing students from public or private institutions knew, there was greater knowledge about the venous lesions.

\section{Collaborations}

Oliveira RL and Falcão LM contributed to the project design, analysis and interpretation of data, writing and relevant critical review of content and final approval of the version to be published. Moura ECC, Avelino FVSD and Machado RS contributed to the data analysis, interpretation of results, relevant critical review of the intellectual content and final approval of the version to be published.

\section{References}

1. Oliveira BGRB, Nogueira GA, Carvalho MR, Abreu AM. Caracterização dos pacientes com úlcera venosa acompanhados no ambulatório de reparo de feridas. Rev Eletr Enf [Internet]. 2012 [citado 2016 fev. 28]; 14(1):156-63. Disponível em:http:// www.fen.ufg.br/revista/v14/n1/v14n1a18.htm

2. Dantas DV, Torres GV, Dantas RAN. Assistência aos portadores de feridas: caracterização dos protocolos existentes no Brasil. Cienc Cuid Saude. 2011; 10(2):366-72.

3. Waidman MAP, Rocha SC, Correa JL, Brischiliari A, Marcon SS. O cotidiano do indivíduo com ferida crônica e sua saúde mental. Texto Contexto Enferm. 2011; 20(4):691-9.

4. Salomé GM, Blanes L, Ferreira LM. Avaliação de sintomas depressivos em pessoas com úlcera venosa. Rev Bras Cir Plást. 2012; 27(1):124-9.

5. Brito CKD, Nottingham IC, Victor JF, Feitoza SMS, Silva MG, Amaral HEG. Venous ulcer: clinical assessment, guidelines and dressing care. Rev Rene. 2013; 14(3):470-80.

6. Malaquias SG, Bachion MM, Sant'Ana SMSC, Dallarmi CCB, Lino Junior RS, Ferreira PS. People with vascular ulcers in outpatient nursing care: a study of sociodemographic and clinical variables. Rev Esc Enferm USP. 2012; 46(2):302-10.

7. Verma H, Tripathi RK. Algorithm-based approach to management of venous leg ulceration. Semin Vasc Surg. 2015; 28(1):54-60.

8. Sant'Ana SMSC, Bachion MM, Santos QR, Nunes $\mathrm{CAB}$, Malaquias SG, Oliveira BGRB. Úlveras venosas: caracterização clínica e tratamento em usuários atendidos em rede ambulatorial. Rev Bras Enferm. 2012: 65(4):637-44.

9. Oliveira JMB, Pinto LO, Lima NGM, Almeida GCM. Câncer de boca: Avaliação do conhecimento de acadêmicos de Odontologia e Enfermagem quanto aos fatores de risco e procedimentos de diagnóstico. Rev Bras Cancerol. 2013; 59(2):211-8.

10. Teixeira E, Fernandes JD, Andrade AC, Silva KL, Rocha MLMO, Lima RJO. Panorama dos cursos de graduação em Enfermagem no Brasil na década das diretrizes curriculares nacionais. Rev Bras Enferm. 2013; 66(n. esp.):102-10. 
11. Silva EGC, Oliveira VC, Neves GBC, Guimarães TMR. Nurses' knowledge about Nursing Care Systematization: from theory to practice. Rev Esc Enferm USP. 2011; 45(6):1380-6.

12. Ahn Y-H, Choi J. Factors affecting Korean nursing student empowerment in clinical practice. Nurse Educ Today. 2015; 35(12):1301-6.
13. Baratiere T, Sangaleti CT, Trincaus MR. Conhecimento de acadêmicos de enfermagem sobre avaliação e tratamento de feridas. Rev Enferm Atenção Saúde [Internet]. 2015 [citado 2016 abr. 22]; 4(1):2-15. Disponível em: http:// seer.uftm.edu.br/revistaeletronica/index.php/ enfer/article/view/1259/1130

15. Sousa ATO, Soares MJGO, Oliveira SHS, Paulo MQ. La biotecnología en el tratamiento de úlcera vascular: estudio de caso. Av Enferm. 2013; 21(2):101-7. 